ELŻBIETA STOJANOWSKA ${ }^{1}$

Studia Psychologica

UKSW

Wydział Psychologii

Wyższa Szkoła Finansów i Zarządzania

16(2) 2016 s. 23-42

Wydział Filozofii Chrześcijańskiej

Instytut Psychologii

Uniwersytet Kardynała Stefana Wyszyńskiego w Warszawie

MARIUSZ BAJ ${ }^{2}$

Wydział Filozofii Chrześcijańskiej

Instytut Psychologii

Uniwersytet Kardynała Stefana Wyszyńskiego w Warszawie

Wydział Pedagogiczny

Uniwersytet Warszawski

\title{
ZADOWOLENIE ZE STUDIÓW U OSÓB Z RÓŻNYM NASILENIEM ORIENTACJI SPOŁECZNYCH JA. ROLA DOŚWIADCZENIA ZDOBYWANEGO NA STUDIACH
}

\section{STRESZCZENIE}

Badania przeprowadzone $\mathrm{w}$ grupie studentów pierwszych lat studiów $(N=302)$ dotyczyły znaczenia orientacji społecznych Ja (według koncepcji Singelisa, Triandisa i współpracowników) oraz doświadczenia nabywanego na studiach w obszarach odpowiadających tym orientacjom dla zadowolenia ze studiów. W badanej grupie orientacje horyzontalne dominowały nad wertykalnymi. Istotnymi wyznacznikami zadowolenia ze studiów było doświadczenie w sferze horyzontalnego kolektywizmu (równościowe relacje koleżeńskie) oraz horyzontalnego indywidualizmu (autonomia), jednak orientacje te same w sobie nie decydowały o poziomie zadowolenia. $\mathrm{W}$ grupie kobiet orientacje wertykalne oraz doświadczenie z nimi związane nie wpływały na zadowolenie, a w grupie mężczyzn wertykalny indywidualizm obniżał ( $w$ niewielkim stopniu) poziom zadowolenia ze studiów.

Słowa kluczowe: orientacje społeczne Ja, autonomia, relacje koleżeńskie, zadowolenie ze studiów, różnice międzypłciowe

1 Adres do korespondencji: elasto@autograf.pl.

2 Adres do korespondencji: mariusz-baj@wp.pl. 


\title{
SATISFACTION WITH THE STUDY AMONG STUDENTS WITH DIFFERENT LEVEL OF SOCIAL ORIENTATIONS OF SELF. THE ROLE OF EXPERIENCE GAINED IN COLLEGE
}

\begin{abstract}
SUMMARY
Research carried out in a group of first years students of study $(N=302)$ concerned the importance of social orientation of self (according to the concept of Singelis, Triandis and co-workers) and experience gained in college in the areas corresponding to these orientations for the satisfaction of the study. The results showed that in the research group horizontal orientations dominated vertical. The important determinants of satisfaction with studies both in women and men were positive experience in the field of horizontal collectivism (supporting peer relationships) and horizontal individualism (autonomy), but immediately those orientations were not determined the satisfaction. Vertical orientations and experience related to them were irrelevant for satisfaction in women, while in men the orientation of vertical individualism disrupted (weakly) the achievement of satisfaction.
\end{abstract}

Keywords: social orientation of self, autonomy, peer relationships, satisfaction with studies, gender differences

\section{WPROWADZENIE TEORETYCZNE}

Współcześnie powszechną formą aktywności młodych ludzi w okresie wczesnej dorosłości jest studiowanie. Studiowanie zaspokaja szereg potrzeb jednostki, nie tylko poznawczych, takich jak rozwój zainteresowań i nabywanie kompetencji potrzebnych w pracy zawodowej, choć te wydają się priorytetowe przy wyborze kierunku studiów. Studiowanie to również wejście w nowe środowisko społeczne, w którym młodzi ludzie nawiązują związki koleżeńskie, przyjacielskie oraz intymne. Dla wielu osób okres pierwszych lat studiów wiąże się z poszukiwaniem i kształtowaniem własnej tożsamości (por. tożsamość moratoryjna: Marcia, 1980; okres przejściowy do wczesnej dorosłości: Levinson, 1986).

Ważnym czynnikiem różnicującym funkcjonowanie psychospołeczne jednostki są orientacje społeczne Ja wyróżnione przez Singelisa, Triandisa i współpracowników (Singelis, Triandis, Bhawuk, Gelfand, 1995; Triandis, Gelfand, 1998), dotyczące przekonań jednostki na temat własnej osoby oraz relacji społecznych.

Orientacje indywidualistyczne charakteryzują jednostki skoncentrowane na tożsamości osobistej (niepowtarzalnym Ja, odrębnym od innych) oraz wewnątrzsterowne: przekonane o osobistym wpływie na cele i efektywność własnego działania.

Orientacje kolektywistyczne dotyczą z kolei jednostek skoncentrowanych na tożsamości społecznej oraz realizacji celów grupowych, przekonane o swoim podobieństwie do otoczenia i współzależności od niego. 
Każda z tych orientacji dzieli się na dwa rodzaje ze względu na przekonania dotyczące porządku społecznego. Orientacje horyzontalne, czyli równościowe, wyrażają przekonanie jednostki o równości ludzi względem siebie, orientacje wertykalne natomiast zakładają strukturę hierarchiczną społeczeństwa, dzielą ludzi na bardziej i mniej ważnych, lepszych i gorszych. Tak więc osoby $\mathrm{z}$ dominującą orientacją horyzontalnego indywidualizmu (HI) koncentrują się na autonomii Ja (realizacji wewnętrznie wyznaczanych celów i sposobów ich osiągania), respektując odrębność i autonomię innych, a osoby z orientacją wertykalnego indywidualizmu (VI), pragnąc wyróżnić się w otoczeniu (być lepszymi od innych) oraz osiągnąć wysoką pozycję społeczną, rywalizują z innymi. Z kolei osoby $\mathrm{z}$ dominującą orientacją horyzontalnego kolektywizmu (HC) cenią współzależność opartą na partnerskich relacjach społecznych, osoby z orientacją wertykalnego kolektywizmu (VC) są zaś autorytarne: przekonane o konieczności podporządkowania indywidualnych potrzeb jednostki interesom grupy, wyznaczanym przez osoby stojące wyżej w hierarchii społecznej.

Orientacje społeczne określają hierarchię potrzeb jednostki. Należy przyjąć, że wymienione wyżej potrzeby: autonomii, partnerskich relacji koleżeńskich, wyróżniania się w otoczeniu czy posłuszeństwa wobec autorytetów występują lub pojawiają się w określonych okolicznościach u wszystkich ludzi, lecz to, co $\mathrm{w}$ tym względzie różni ludzi między sobą, to znaczenie nadawane przez nich tym potrzebom, siła i częstość ich przeżywania. Tak więc dla osób z dominującą orientacją HI najważniejsza jest autonomia, a dla osób z orientacją VI - sukces wyróżniający jednostkę z otoczenia. Z kolei dla osób $\mathrm{z}$ dominującą orientacją HC pierwszoplanowe są bliskie partnerskie relacje koleżeńskie, a dla osób z VC posłuszeństwo i poświęcenie dla dobra własnej grupy.

Celem badań zaprezentowanych w niniejszym artykule jest uzyskanie odpowiedzi na pytanie, czy zadowolenie ze studiów, rozumiane jako subiektywny dobrostan psychiczny, wynikający ze studiowania, zależy od orientacji społecznych Ja oraz czy jest osiągane w odmienny sposób przez osoby o różnych orientacjach. W tej kwestii można sformułować alternatywne hipotezy. Pierwsza z nich przewiduje, że osoby o różnych orientacjach społecznych Ja osiągają zadowolenie ze studiów wtedy, gdy zaspokajają potrzeby ważne dla tych orientacji. Oznacza to również, że zaspokajanie tych samych potrzeb (to samo doświadczenie) ma zróżnicowane konsekwencje dla dobrostanu psychicznego osób o różnych orientacjach społecznych Ja. Na przykład dobre relacje koleżeńskie mają większy wpływ na zadowolenie ze studiów u osób z silną orientacją HC $\mathrm{w}$ porównaniu $\mathrm{z}$ osobami o słabej orientacji HC. Z kolei swoboda działania i rozwijanie własnych zainteresowań $\mathrm{w}$ większym stopniu przyczyniają się do zadowolenia ze studiów u osób z silną orientacją HI w porównaniu z osobami o słabej orientacji HI. W powyższym rozumowaniu przyjmuje się założenie, że możliwe jest zdobywanie pozytywnego doświadczenia w sferze nieodpowiadającej dominującej orientacji społecznej jednostki. I tak osoba ze słabą orientacją 
horyzontalnego kolektywizmu, niezabiegająca o udane relacje koleżeńskie, może takie relacje mieć z powodu swoich przymiotów osobistych (na przykład dużej atrakcyjności fizycznej) bądź przyjaźnie nastawionego otoczenia, nie traktuje jednak tych relacji jako głównego źródła satysfakcji ze studiów. Z kolei osoba ze słabą orientacją wertykalnego indywidualizmu może zajmować wysoką pozycję w grupie z powodu swoich zdolności i umiejętności, a nie z powodu tego, że na takiej pozycji jej zależało; nie będzie też doświadczenia bycia lepszą traktować jako podstawy swojego zadowolenia ze studiów. Podsumowując: hipoteza pierwsza przewiduje, że każda orientacja społeczna Ja może prowadzić do podobnego poziomu dobrostanu psychicznego, pod warunkiem że zaspokajane są ważne dla tej orientacji potrzeby.

Powstaje jednak wątpliwość, czy zaspokajając potrzeby ważne dla orientacji Ja, osoby o różnych orientacjach społecznych faktycznie osiągają podobny poziom zadowolenia ze studiów. Na przykład czy osoby z dominującą orientacją VC, akceptujące i doświadczające podporządkowania własnych pragnień interesom grupy, są równie zadowolone ze studiów, jak osoby z dominującą orientacją HC, nawiązujące udane partnerskie relacje koleżeńskie. W związku z tą wątpliwością sformułowano drugą hipotezę alternatywną. Przewiduje ona, że osoby o dominującej określonej orientacji społecznej Ja mają zróżnicowane szanse osiągnięcia zadowolenia ze studiów, gdyż specyficzna hierarchia potrzeb związana z tymi orientacjami w niejednakowym stopniu przyczynia się do życiowej satysfakcji. Hipoteza ta opiera się na stanowisku i badaniach wielu autorów (Argyle, 2004; Nezleck, 2004; Baumeister, Leary, 1995; Deci, Ryan, 2000; Ryan, Deci, 2000) mówiących o uniwersalnych ludzkich potrzebach, których zaspokojenie prowadzi do dobrostanu psychicznego. W ewolucyjnej koncepcji przynależności Baumeistera i Leary'ego (1995), mającej silne umocowanie w rozlicznych badaniach (ibidem; zob. też: Argyle, 2004; Baumeister, DeWall, Ciarocco, Twenge, 2005; Nezleck, 2004), potrzeba więzi społecznych, zaspokajana przez bliskie, wzajemne relacje $\mathrm{z}$ innymi, jest najważniejszym predyktorem dobrostanu psychicznego jednostki. Z kolei w koncepcji samodeterminacji Deciego i Ryana (2000) wprawdzie wyróżnia się trzy uniwersalne potrzeby ludzi: autonomii, kompetencji i przynależności, jednak uważa się, że potrzeba autonomii jest podstawowa, a jej zaspokojenie stanowi warunek konieczny osiągnięcia subiektywnego dobrostanu psychicznego oraz rozwoju zrównoważonej, silnej osobowości. Nie wnikając w złożone relacje potrzeby przynależności z potrzebą autonomii, można oczekiwać, że osoby o silnych orientacjach horyzontalnych, skoncentrowane na bliskich, opartych na wzajemności relacjach z ludźmi (HC) bądź/i rozwoju własnej autonomii (HI), mają większe szanse na osiągnięcie zadowolenia ze studiów niż osoby o orientacjach wertykalnych, uznające nierówność między ludźmi, a tym samym konieczność podporządkowania swoich pragnień interesom grupy (VC) lub opanowanych przez narażającą na permanentny stres potrzebę rywalizacji (VI). Innymi słowy, jednostki o orientacjach wertykalnych koncentrują się na potrzebach, które mogą 
utrudniać zaspokojenie potrzeb rzeczywiście ważnych dla dobrostanu psychicznego, pragną czegoś, co osiągnięciu tego stanu nie sprzyja. Podsumowując: druga alternatywna hipoteza przewiduje, że osoby o dominujących orientacjach horyzontalnych są bardziej zadowolone ze studiów niż osoby o dominujących orientacjach wertykalnych, gdyż te pierwsze orientacje ułatwiają zdobywanie pozytywnego doświadczenia w sferach istotnych dla dobrostanu psychicznego.

Orientacje społeczne Ja określają obszary życia ważne dla jednostki, nie wskazują jednak bezpośrednio na stopień efektywności, z jaką jednostka zaspokaja potrzeby związane $\mathrm{z}$ tymi orientacjami. Tak więc $\mathrm{z}$ faktu, że student pierwszego roku ceni bliskie relacje społeczne, nie wynika wprost, że w nowym otoczeniu nawiązał takie relacje, a z faktu, że dla kogoś rywalizacja ",jest wszystkim”, nie wynika jeszcze, że w określonej grupie i czasie (na przykład podczas pierwszego roku studiów) wychodzi z rywalizacji zwycięsko. Wprawdzie biorąc pod uwagę perspektywę długofalowego rozwoju i kształtowania się orientacji społecznych Ja, należałoby sądzić, że pozytywne doświadczenie w określonych obszarach życia ma wpływ na rozwój odpowiadającej im orientacji (ludzie cenią to, w czym czują się kompetentni lub/i są za to nagradzani), jednak ukształtowana orientacja nie decyduje automatycznie o poziomie zaspokojenia związanych $\mathrm{z}$ nią potrzeb w każdym środowisku. Możliwa jest zatem jeszcze inna prawidłowość: Trzecia alternatywna hipoteza przewiduje względną niezależność doświadczenia zdobywanego na studiach oraz zadowolenia ze studiów od orientacji społecznych Ja, przewiduje natomiast bezpośrednią zależność zadowolenia od doświadczenia zdobywanego na studiach. Oczekiwana niezależność wynikałaby ze złożonych uwarunkowań nabywania pozytywnego doświadczenia. Nie wystarczy cenić dobre relacje z ludźmi (czyli mieć silną orientację HC), aby zdobywać pozytywne doświadczenie $w$ tej sferze, trzeba umieć takie relacje nawiązywać i utrzymywać. Nie wystarczy cenić autonomię (mieć silną orientację HI), aby jej doświadczać; trzeba też, między innymi, przebywać w otoczeniu, które respektuje wolność wyborów oraz szanuje prywatność jednostki. Nie wystarczy chcieć być lepszym od innych (czyli mieć silną orientację VI), trzeba osiągać sukcesy wyróżniające jednostkę wśród innych, a do tego potrzebne są odpowiednie zalety sprawnościowe. Innymi słowy, to pozytywne doświadczenie decyduje o zadowoleniu ze studiów, a nie same orientacje społeczne Ja, które wprawdzie motywują jednostkę do zaspokajania określonych potrzeb, ale bezpośrednio tego nie gwarantują. W hipotezie trzeciej, podobnie jak w hipotezie drugiej, oczekuje się, że doświadczenie w sferze autonomii i partnerskich relacji społecznych przyczynia się do dobrostanu psychicznego bardziej niż doświadczenie związane z osiąganiem wysokiej pozycji w grupie.

Jaką rolę w opisanych prawidłowościach odgrywa płeć jednostki? Po pierwsze można oczekiwać, że ewentualne różnice między kobietami i mężczyznami wynikają ze zróżnicowanego nasilenia orientacji społecznych Ja, powodującego, że o zadowoleniu ze studiów będzie decydował inny rodzaj doświadczenia. Zgodnie 
z treścią stereotypów płciowych kobiety uważane są za osoby bardziej wspólnotowe niż mężczyźni, a mężczyźni za osoby bardziej indywidualistyczne od kobiet; wiele różnic płciowych $\mathrm{w}$ funkcjonowaniu emocjonalno-społecznym jednostki można wyjaśniać, odwołując się do nasilenia Ja niezależnego i Ja współzależnego kobiet i mężczyzn (Cross, Madson, 1997). Po drugie można przypuszczać, że płeć jest moderatorem zależności między orientacjami społecznymi Ja i doświadczeniem a dobrostanem psychicznym, czyli podobne nasilenie orientacji Ja oraz podobny rodzaj doświadczenia mogą mieć inny wpływ na zadowolenie ze studiów osób o różnej płci. Przyczyną są odmienne oczekiwania społeczne wobec kobiet i mężczyzn (Eagly, 1987; Heilman, Chen, 2005; Rudman, Fairland, 2004). Tak więc kobiety mogą czerpać większe zadowolenie z bliskich relacji koleżeńskich w środowisku studenckim, a mężczyźni - z niezależności i swobody działania, dlatego że tego się od nich oczekuje i takie zachowania akceptuje.

W niniejszych badaniach nie formułowano oczekiwań dotyczących struktury nasilenia orientacji społecznych Ja wśród badanych studentów. Można było oczywiście snuć przypuszczenia, że ethos uczelni (np. katolicki/świecki) skupia młodzież o wybranych dominujących orientacjach społecznych Ja i tym samym promuje zdobywanie określonego rodzaju doświadczenia. W polskim społeczeństwie obecne są dwie ideologie: konserwatywna i liberalna (por. Reykowski, 2013). Pierwsza z nich traktuje wspólnotę jako wartość nadrzędną, ściśle powiązaną z religią i tradycją, wobec której jednostka zobowiązana jest do lojalności i podporządkowania. Druga ideologia promuje wartości indywidualistyczne, prymat praw jednostki nad prawami grupy, a więc bycie we wspólnocie ma charakter dobrowolny i równościowy. Ideologii konserwatywnej odpowiada orientacja wertykalnego kolektywizmu, ideologii liberalnej bliższe są orientacje horyzontalne. Wybór uczelni zależy od wielu przyczyn, wśród których wyznawany światopogląd jest tylko jedną z wielu, dlatego nie formułowano oczekiwań odnośnie do nasilenia orientacji społecznych Ja w badanej grupie. Niniejsze badania nie odpowiadają też na pytanie ogólne: jakie orientacje społeczne Ja dominują wśród polskich studentów? Badania objęły tylko jedną uczelnię, a więc uzyskane wyniki nie pozwalają dokonywać generalizacji na całą populację studentów w Polsce.

\section{METODA}

\section{Osoby badane}

Osobami, u których zbadano orientacje społeczne Ja, doświadczenie na studiach oraz zadowolenie ze studiów, były 302 osoby ( 86 mężczyzn i 216 kobiet) w wieku 19-21 lat $(M=20,3)$, studenci dwóch pierwszych lat studiów Uniwersytetu Kardynała Stefana Wyszyńskiego na kierunkach: psychologia $(n=49)$, prawo $(n=50)$, pedagogika $(n=50)$, filozofia $(n=55)$, socjologia $(n=48)$ oraz ochrona środowiska $(n=55)$. Średnia wieku osób badanych wynosiła 20,03 . 


\section{Metoda pomiaru czterech orientacji społecznych Ja}

Podstawą do opracowania metody była oryginalna, 32-zdaniowa metoda Singelisa, Triandisa i współpracowników (1995), opisująca cztery orientacje: HC, HI, VC i VI - po osiem zdań dla każdej orientacji. Osoby badane oceniają na skali 1-9, w jakim stopniu odnosi się do nich każde zdanie, gdzie 1 oznacza: nigdy, 9 natomiast - zawsze, zdecydowanie tak. Metoda ta została przetłumaczona na język polski, a następnie - w celu weryfikacji poprawności wersji polskiej - na język angielski.

Metodę (niepublikowaną wcześniej) wykorzystaną w badaniach opracowała autorka niniejszego artykułu na podstawie wyników 885 osób, studentów studiów stacjonarnych i niestacjonarnych (363 mężczyzn i 522 kobiet w wieku $M=30,6 ; M e=26,00)$. Uzyskany wynik miary adekwatności próby jest zadowalający: $\mathrm{KMO}=0,715$. Za pomocą eksploracyjnej analizy czynnikowej metodą głównych składowych wyodrębniono cztery czynniki, treściowo zgodne z czterema orientacjami Ja, które wyjaśniają 56,5\% wariancji wszystkich wyników. Oryginalna metoda została jednak mocno zredukowana i w ostatecznej polskiej wersji znalazło się tylko 14 zdań: po cztery zdania dla orientacji HC i HI oraz po trzy zdania dla orientacji VI i VC.

Tabela nr 1 przedstawia macierz rotowanych składowych (po zastosowaniu rotacji ortogonalnej Varimax), w której pierwszy czynnik odpowiada orientacji horyzontalnego kolektywizmu (HC), drugi czynnik - horyzontalnego indywidualizmu (HI), trzeci czynnik - orientacji wertykalnego indywidualizmu (VI) i czwarty czynnik - orientacji wertykalnego kolektywizmu (VC). Dla każdego czynnika sprawdzono jego rzetelność. Wartości alfa Cronbacha wyniosły odpowiednio: dla $\mathrm{HC}-0,74$, dla $\mathrm{HI}-0,64$, dla VI - 0,73 i dla VC - 0,53.

Tabela 1

Macierz rotowanych czynników dla czterech orientacji społecznych Ja

\begin{tabular}{|c|c|c|c|c|}
\hline Treść zdań & 1 & 2 & 3 & 4 \\
\hline $\begin{array}{l}\text { Ważne jest dla mnie dobre samopoczucie } \\
\text { moich współpracowników (kolegów). }\end{array}$ & 0,837 & & & \\
\hline $\begin{array}{l}\text { Czuję się dumny, gdy mój współpracownik } \\
\text { (kolega) otrzymuje nagrodę. }\end{array}$ & 0,753 & & & \\
\hline $\begin{array}{l}\text { Jest dla mnie ważne, aby utrzymać harmonię } \\
\text { w mojej grupie. }\end{array}$ & 0,743 & & & 0,171 \\
\hline Dobrze się czuję, gdy współpracuję z innymi. & 0,621 & 0,233 & & 0,189 \\
\hline $\begin{array}{l}\text { Moje sukcesy są zwykle efektem moich } \\
\text { zdolności. }\end{array}$ & & 0,744 & & \\
\hline $\begin{array}{l}\text { To, co dzieje się w moim życiu, jest efektem } \\
\text { mojego działania. }\end{array}$ & & 0,683 & & \\
\hline
\end{tabular}

Ciąg dalszy tabeli na następnej stronie 
Ciąg dalszy tabeli z poprzedniej strony

\begin{tabular}{|c|c|c|c|c|}
\hline Treść zdań & 1 & 2 & 3 & 4 \\
\hline Często „robię swoje”. & & 0,659 & 0,134 & \\
\hline $\begin{array}{l}\text { Cieszę się, że jestem dla innych } \\
\text { niepowtarzalny. }\end{array}$ & & 0,631 & 0,135 & \\
\hline $\begin{array}{l}\text { Irytuje mnie, gdy inni wykonują zadanie } \\
\text { lepiej ode mnie. }\end{array}$ & & & 0,890 & \\
\hline $\begin{array}{l}\text { Robię się napięty i pobudzony, gdy inni } \\
\text { osiągają wyniki lepsze od moich. }\end{array}$ & & & 0,851 & 0,133 \\
\hline $\begin{array}{l}\text { Jest dla mnie ważne, że wykonuję swoją } \\
\text { pracę lepiej niż inni. }\end{array}$ & & 0,376 & 0,571 & 0,183 \\
\hline $\begin{array}{l}\text { Dla rodziny poświęciłbym aktywność, którą } \\
\text { bardzo lubię, jeśliby jej nie akceptowała. }\end{array}$ & & & & 0,781 \\
\hline $\begin{array}{l}\text { Zrobiłbym to, co lubi moja rodzina, nawet } \\
\text { jeśli byłaby to rzecz, której nie cierpię. }\end{array}$ & 0,216 & & 0,130 & 0,703 \\
\hline $\begin{array}{l}\text { Nienawidzę nie zgadzać się z innymi z mojej } \\
\text { grupy. }\end{array}$ & & & 0,207 & 0,599 \\
\hline
\end{tabular}

\section{Metoda oceny doświadczenia na studiach}

Ułożono 16 zdań opisujących pozytywne doświadczenie w obszarach nawiązujących do orientacji społecznych Ja, po cztery zdania dla każdej orientacji (załącznik A). Treść zdań została opracowana przez studentów psychologii UKSW, po zapoznaniu się ze specyfiką czterech orientacji Ja. Osoby badane oceniały na skali 1-7, w jakim stopniu zgadzają się z każdym zdaniem, gdzie 1 oznaczało: zupetnie tak nie jest, 7 natomiast - zdecydowanie tak jest. Metodą tą przebadano 302 studentów pierwszych lat studiów na Uniwersytecie Kardynała Stefana Wyszyńskiego w Warszawie. Na podstawie eksploracyjnej analizy czynnikowej, przy użyciu metody głównych składowych wyodrębniono trzy czynniki, które łącznie wyjaśniają około $54 \%$ wariancji wyników dla tej zmiennej. Współczynnik adekwatności próby KMO wynosi 0,754.

Tabela nr 2 przedstawia macierz rotowanych składowych (po zastosowaniu rotacji ortogonalnej Varimax). Pierwszy czynnik obejmuje zdania opisujące doświadczenie ważne dla orientacji horyzontalnego kolektywizmu (HC), drugi czynnik uwzględnia doświadczenie istotne dla orientacji wertykalnego indywidualizmu (VI), trzeci czynnik dotyczy znaczącego doświadczenia dla orientacji horyzontalnego indywidualizmu (HI). Z analizy wyników dla doświadczenia na studiach odrzucono cztery zdania dotyczące głównie potrzeb związanych z orientacją wertykalnego kolektywizmu, ze względu na słabe zasoby wspólne tych zdań. Dla każdego czynnika sprawdzono jego rzetelność. Wartości alfa Cronbacha wyniosły odpowiednio: dla $\mathrm{HC}_{\text {dos }}: 0,76$, dla $\mathrm{HI}_{\mathrm{dos}}: 0,60, \mathrm{dla} \mathrm{VI}_{\mathrm{dos}}: 0,66$. 
Czynnik 1 to doświadczenie ważne dla horyzontalnego kolektywizmu $\left(\mathrm{HC}_{\mathrm{dos}}\right)$. Wysokie wyniki uzyskane w tym czynniku oznaczają, że jednostka czerpie satysfakcję z udanych relacji koleżeńskich na studiach, przyjemnego spędzania czasu z innymi oraz tego, że może liczyć na ich wsparcie i akceptację - zaspokaja poczucie przynależności. Czynnik 2 to doświadczenie ważne dla osób o orientacji wertykalnej $\left(\mathrm{VI}_{\text {dos }}\right)$. Wysokie wyniki oznaczają, że jednostka doświadcza bycia lepszą od innych: czuje się bardziej kompetentna oraz jest autorytetem dla swoich kolegów w grupie. Z kolei czynnik 3 to doświadczenie ważne dla horyzontalnego indywidualizmu $\left(\mathrm{HI}_{\mathrm{dos}}\right)$. Wysokie wyniki tego czynnika oznaczają, że jednostka zaspokaja potrzebę autonomii na studiach: robi to, co lubi, rozwija własne zainteresowania, czuje się wolna i zachowuje własną prywatność.

Tabela 2

Macierz rotowanych czynników dla zmiennej doświadczenie na studiach

\begin{tabular}{|c|c|c|c|}
\hline Treść zdań & 1 & 2 & 3 \\
\hline Miło spędzam czas z kolegami po zajęciach. & 0,785 & & \\
\hline Na studiach nawiązałem nowe znajomości i przyjaźnie. & 0,742 & 0,192 & 0,108 \\
\hline Mogę liczyć na wzajemną pomoc kolegów i koleżanek. & 0,729 & $-0,152$ & 0,283 \\
\hline $\begin{array}{l}\text { Koledzy i koleżanki ze studiów cieszą się, kiedy jestem } \\
\text { w ich towarzystwie. }\end{array}$ & 0,713 & 0,222 & 0,114 \\
\hline $\begin{array}{l}\text { W dyskusji z kolegami mam do powiedzenia więcej } \\
\text { od innych. }\end{array}$ & & 0,726 & \\
\hline $\begin{array}{l}\text { Moje prace zaliczeniowe należą do jednych } \\
\text { z ciekawszych. }\end{array}$ & & 0,677 & 0,226 \\
\hline $\begin{array}{l}\text { Koledzy pytają mnie o radę w ważnych dla grupy } \\
\text { sprawach. }\end{array}$ & 0,380 & 0,659 & $-0,106$ \\
\hline $\begin{array}{l}\text { Prowadzący wyróżnia moje opinie podczas dyskusji } \\
\text { grupowej na zajęciach. }\end{array}$ & & 0,648 & 0,321 \\
\hline $\begin{array}{l}\text { Prowadzący zajęcia pozwalają mi na kreatywność } \\
\text { i swobodę wypowiedzi. }\end{array}$ & & 0,243 & 0,758 \\
\hline $\begin{array}{l}\text { Rozwijam swoje zainteresowania na zajęciach } \\
\text { organizowanych przez uczelnię. }\end{array}$ & 0,113 & 0,188 & 0,623 \\
\hline Mam na studiach dużą swobodę: robię to, co lubię. & 0,238 & & 0,617 \\
\hline $\begin{array}{l}\text { Na studiach mogę zachować własną prywatność - nikt } \\
\text { nie wtrąca się w moje sprawy. }\end{array}$ & & & 0,590 \\
\hline
\end{tabular}

\section{Metoda badania zadowolenia ze studiów}

Skala zadowolenia ze studiów została utworzona na podstawie Skali zadowolenia $z \dot{z} y c i a$ (Diener, Emmons, Larson, Griffin, 1985; tłum. pol.: Diener, Lucas, Oishi, 2004). W miejsce określenia $\dot{z} y c i e$ (w metodzie oryginalnej) wprowadzono słowo 
studia. Skala zawiera pięć stwierdzeń. Badany ocenia, w jakim stopniu każde $\mathrm{z}$ nich odnosi się do jego dotychczasowego życia studenckiego. Wskaźnikiem zadowolenia jest średni wynik dla pięciu zdań. Skale charakteryzuje wysoka rzetelność: alfa Cronbacha wynosi 0,84. Ułożone zdania brzmią następująco:

1. Pod wieloma względami moje studiowanie jest bliskie ideału.

2. Mam doskonałe warunki do studiowania.

3. Jestem zadowolony ze swoich studiów.

4. Jak dotad realizuje na studiach to, co jest dla mnie ważne.

5. Jeśli miałbym dokonać wyboru jeszcze raz, wybrałbym te same studia.

Osoby badane oceniały na skali 1-7, w jakim stopniu zgadzają się z każdym zdaniem, gdzie 1 oznacza: Całkowicie się nie zgadzam, 2 - Nie zgadzam się, 3 - Raczej się nie zgadzam, 4 - Ani jedno, ani drugie, 5 - Raczej się zgadzam, 6 - Zgadzam się, 7 natomiast - Całkowicie się zgadzam. Skalą tą przebadano 302 studentów.

\section{WYNIKI}

\section{Analizy wstępne}

Tabela 3 przedstawia wyniki surowe dla orientacji społecznych Ja, rodzajów doświadczenia oraz zadowolenia ze studiów w grupie kobiet $(n=216)$ i mężczyzn $(n=86)$.

Wykonano analizę wariancji $\mathrm{z}$ powtarzanym pomiarem $\mathrm{w}$ schemacie płeć $(2) \times$ rodzaj orientacji (4). Uzyskano istotny statystycznie efekt interakcyjny obu zmiennych: $F(2,298)=8,82 ; p<0,001 ; \eta^{2}=0,08$. Zarówno w grupie kobiet, jak i mężczyzn orientacje horyzontalne (HC i HI) dominowały nad orientacjami wertykalnymi (VC i VI). W grupie mężczyzn orientacja HI była w niewielkim, acz istotnym stopniu silniejsza od orientacji HC, w grupie kobiet natomiast obie te orientacje były równie silne. Średnie nasilenie obu orientacji horyzontalnych było zdecydowanie wyższe od teoretycznej średniej na dziewięciopunktowej skali zastosowanej do pomiaru zmiennych $\left(M_{\text {teoretyczan }}=4,5\right)$, a rozkład zmiennych ujemnie skośny - dominowały wartości powyżej średniej. Orientacje wertykalne osiągnęły wartości bardziej zbliżone do średnich wartości skali. Wyniki kobiet w niewielkim stopniu różniły się od wyników mężczyzn (wartości $d$ mieszczą się w obszarze niskich różnic): mężczyźni wykazali nieco wyższe nasilenie orientacji HI od kobiet, a te z kolei wykazywały trochę silniejsze natężenie orientacji VI niż mężczyźni. 


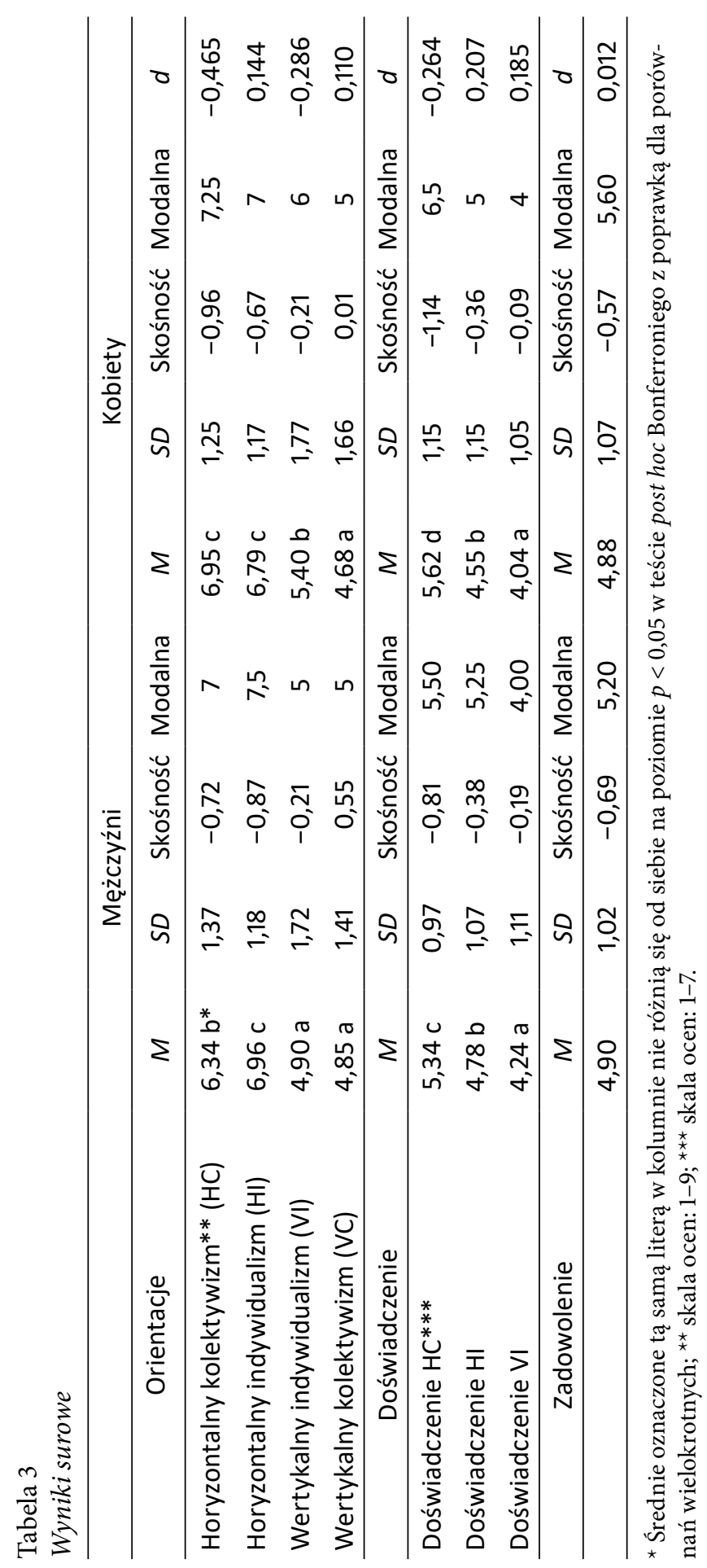


Podobnie dla pozytywności doświadczenia wykonano analizę wariancji $\mathrm{z}$ powtarzanym pomiarem $\mathrm{w}$ schemacie płeć $(2) \times$ rodzaj doświadczenia (3). Uzyskano efekt interakcyjny obu zmiennych: $F(2,299)=5,80 ; p<0,01 ; \eta^{2}=0,04$. Zarówno kobiety, jak i mężczyźni najlepiej zaspokajali potrzeby afiliacyjne związane z orientacją horyzontalnego kolektywizmu: średnia pozytywność doświadczeń związanych z tą orientacją $\left(\mathrm{HC}_{\mathrm{dos}}\right)$ była zdecydowanie wyższa od średniej teoretycznej na skali siedmiopunktowej zastosowanej do pomiaru pozytywności doświadczenia $\left(M_{\text {teoretyczna }}=3,50\right)$ : rozkłady tej zmiennej są ujemnie skośne, czyli dominują wartości powyżej średniej. Potrzeba zachowania autonomii $\left(\mathrm{HI}_{\mathrm{dos}}\right)$ zajmuje drugie miejsce pod względem stopnia jej zaspokojenia w obu grupach płciowych. Wartości tej zmiennej pozycjonują się również powyżej średniej teoretycznej i przedstawiają rozkład ujemnie skośny. Stosunkowo najsłabiej, ale nadal na poziomie nasilenia średniego, są zaspokajane potrzeby związane z rywalizacją, faworyzowaniem własnego Ja. Mężczyźni w niewielkim stopniu niżej (wartości $d=-0,26)$ niż kobiety oceniają zaspokajanie potrzeb afiliacyjnych. $\mathrm{W}$ zakresie pozostałych dwóch rodzajów doświadczeń związanych $\mathrm{z}$ autonomią $\left(\mathrm{HI}_{\text {dos }}\right)$ i rywalizacją $\left(\mathrm{VI}_{\text {dos }}\right)$ nie wykazano różnic międzypłciowych.

Zadowolenie ze studiów kobiety i mężczyźni deklarowali na ponadprzeciętnym poziomie. Nie wykazano tu różnic międzypłciowych $(p>0,9)$. W zakresie tej zmiennej rozkład ma również charakter ujemnie skośny, czyli ponadprzeciętne zadowolenie deklaruje zdecydowana większość badanych studentów. Kolejne analizy dotyczą korelacji między zmiennymi (tabela 4).

Tabela 4

Analizy korelacyjne - powyżej przekątnej wyniki mężczyzn $(N=86)$, poniżej - kobiet $(N=216)$

\begin{tabular}{|c|c|c|c|c|c|c|c|c|}
\hline Zmienne & 1 & 2 & 3 & 4 & 5 & 6 & 7 & 8 \\
\hline Zadowolenie & $x$ & 0,17 & $-0,01$ & $-0,22 *$ & $-0,03$ & $0,21^{*}$ & $0,67^{* *}$ & 0,12 \\
\hline $\begin{array}{l}\text { Horyzontalny } \\
\text { kolektywizm } \\
\text { (HC) }\end{array}$ & 0,13 & $x$ & 0,14 & $-0,15$ & 0,09 & $0,55^{* *}$ & $0,24^{*}$ & $0,36 * *$ \\
\hline $\begin{array}{l}\text { Horyzontalny } \\
\text { indywidualizm } \\
\text { (HI) }\end{array}$ & 0,03 & $0,24^{* *}$ & $x$ & $-0,01$ & $-0,04$ & 0,14 & 0,03 & $0,33^{* *}$ \\
\hline $\begin{array}{l}\text { Wertykalny } \\
\text { indywidualizm } \\
\text { (VI) }\end{array}$ & $-0,03$ & $-0,12$ & $0,19 *$ & $x$ & 0,03 & $-0,08$ & $-0,03$ & 0,14 \\
\hline $\begin{array}{l}\text { Wertykalny } \\
\text { kolektywizm } \\
\text { (VC) }\end{array}$ & 0,09 & 0,09 & 0,01 & $0,18^{*}$ & $x$ & 0,08 & $-0,05$ & $0,23^{*}$ \\
\hline
\end{tabular}


Ciąg dalszy tabeli z poprzedniej strony

\begin{tabular}{lcccccccc}
\hline \multicolumn{1}{c}{ Zmienne } & 1 & 2 & 3 & 4 & 5 & 6 & 7 & 8 \\
\hline $\begin{array}{l}\text { Doświadczenie } \\
\text { HC }\end{array}$ & $0,34^{* *}$ & $0,54^{* *}$ & $0,22^{* *}$ & $-0,02$ & $0,18^{*}$ & $\mathrm{x}$ & 0,21 & $0,52^{* *}$ \\
$\begin{array}{l}\text { Doświadczenie } \\
\text { HI }\end{array}$ & $0,45^{* *}$ & $0,31^{* *}$ & $0,28^{* *}$ & $-0,01$ & 0,03 & $0,37^{* *}$ & $\mathrm{x}$ & 0,17 \\
$\begin{array}{l}\text { Doświadczenie } \\
\text { VI }\end{array}$ & 0,12 & $0,21^{*}$ & $0,36^{* *}$ & $0,21^{* *}$ & 0,06 & $0,21^{* *}$ & $0,35^{* *}$ & $\mathrm{X}$ \\
\hline
\end{tabular}

${ }^{*} p<0,05 ;{ }^{* *} p<0,01$.

W grupie kobiet uzyskano niewysokie korelacje dodatnie między orientacjami horyzontalnymi $(0,24)$ i między orientacjami wertykalnymi $(0,18)$. W grupie mężczyzn nasilenie czterech orientacji nie korelowało między sobą.

Zarówno w grupie kobiet, jak i mężczyzn zadowolenie ze studiów jest pozytywnie skorelowane $\mathrm{z}$ doświadczeniem w sferach HC i HI. Ponadto w grupie mężczyzn orientacja VI była skorelowana $\mathrm{z}$ zadowoleniem negatywnie. Jest to jedyna orientacja społeczna Ja bezpośrednio związana $\mathrm{z}$ zadowoleniem ze studiów (ale tylko w grupie mężczyzn).

W grupie mężczyzn orientacja HC korelowała pozytywnie z doświadczeniem nie tylko $w$ tej sferze, lecz także $w$ dwóch pozostałych. Jednak już doświadczenia w sferze autonomii $\left(\mathrm{HI}_{\mathrm{dos}}\right)$ oraz zwycięskiej rywalizacji $\left(\mathrm{VI}_{\mathrm{dos}}\right)$ nie były skorelowane z odpowiadającymi im orientacjami (HI i VI) w grupie mężczyzn.

W grupie kobiet orientacje HC i HI korelowały pozytywnie z doświadczeniem nie tylko w sferach im odpowiadających, lecz także w sferze VI. Z kolei orientacja VI korelowała pozytywnie $\mathrm{z}$ doświadczeniem tylko $\mathrm{w}$ tej sferze $\left(\mathrm{VI}_{\mathrm{dos}}\right)$, a orientacja $\mathrm{VC}-\mathrm{z}$ doświadczeniem w sferze partnerskich relacji koleżeńskich $\left(\mathrm{HC}_{\mathrm{dos}}\right)$.

\section{Weryfikacja hipotez}

Dla zadowolenia ze studiów wykonano analizę regresji hierarchicznej (tabela 5).

Tabela 5

Hierarchiczna analiza regresji dla zadowolenia ze studiów

\begin{tabular}{lccccc}
\hline \multicolumn{1}{c}{ Zmienne } & $B$ & $S E B$ & Beta & $\begin{array}{c}\text { Skorygo- } \\
\text { wane } R^{2}\end{array}$ & $\Delta R^{2}$ \\
\hline I krok & & & & & \\
Płeć & $-0,028$ & 0,076 & $-0,022$ & 0,012 & 0,029 \\
Horyzontalny kolektywizm & 0,151 & 0,070 & $0,132 *$ & & \\
Horyzontalny indywidualizm & $-0,004$ & 0,068 & $-0,003$ & & \\
Wertykalny indywidualizm & $-0,093$ & 0,068 & 0,082 & & \\
Wertykalny kolektywizm & 0,059 & 0,067 & 0,051 & & \\
\hline
\end{tabular}

Ciąg dalszy tabeli na następnej stronie 
Ciąg dalszy tabeli z poprzedniej strony

\begin{tabular}{|c|c|c|c|c|c|}
\hline Zmienne & $B$ & $S E B$ & Beta & $\begin{array}{l}\text { Skorygo- } \\
\text { wane } R^{2}\end{array}$ & $\Delta R^{2}$ \\
\hline \multicolumn{6}{|l|}{ II krok } \\
\hline Płeć & 0,054 & 0,066 & 0,043 & 0,289 & $0,279 * *$ \\
\hline \multicolumn{6}{|l|}{ Horyzontalny kolektywizm } \\
\hline$(\mathrm{HC})$ & $-0,117$ & 0,070 & $-0,102$ & & \\
\hline \multicolumn{6}{|c|}{ Horyzontalny indywidualizm } \\
\hline (HI) & $-0,107$ & 0,060 & $-0,094$ & & \\
\hline \multicolumn{6}{|l|}{ Wertykalny indywidualizm } \\
\hline (VI) & $-0,103$ & 0,059 & $-0,090$ & & \\
\hline Wertykalny kolektywizm (VC) & 0,044 & 0,057 & 0,038 & & \\
\hline Doświadczenie $\mathrm{HC}$ & 0,230 & 0,069 & $0,202 * *$ & & \\
\hline Doświadczenie HI & 0,574 & 0,061 & $0,503 * *$ & & \\
\hline Doświadczenie VI & $-0,023$ & 0,064 & $-0,020$ & & \\
\hline \multicolumn{6}{|l|}{ III krok } \\
\hline Płeć & 0,093 & 0,069 & 0,073 & 0,318 & 0,053 \\
\hline \multicolumn{6}{|l|}{ Horyzontalny kolektywizm } \\
\hline$(\mathrm{HC})$ & $-0,102$ & 0,075 & $-0,089$ & & \\
\hline \multicolumn{6}{|c|}{ Horyzontalny indywidualizm } \\
\hline (HI) & $-0,100$ & 0,066 & $-0,088$ & & \\
\hline \multicolumn{6}{|l|}{ Wertykalny indywidualizm } \\
\hline$(\mathrm{VI})$ & $-0,182$ & 0,065 & $-0,159 * *$ & & \\
\hline Wertykalny kolektywizm (VC) & 0,022 & 0,068 & 0,019 & & \\
\hline Doświadczenie HC & 0,209 & 0,090 & $0,183^{*}$ & & \\
\hline Doświadczenie HI & 0,684 & 0,068 & $0,599 * *$ & & \\
\hline Doświadczenie VI & 0,014 & 0,076 & 0,012 & & \\
\hline $\mathrm{HC} \times$ doświadczenie HC & 0,034 & 0,047 & 0,042 & & \\
\hline $\mathrm{HI} \times$ doświadczenie HI & 0,014 & 0,060 & 0,012 & & \\
\hline VI × doświadczenie VI & 0,065 & 0,058 & 0,057 & & \\
\hline VC $\times$ doświadczenie VI & $-0,064$ & 0,058 & 0,055 & & \\
\hline $\mathrm{HC} \times$ płeć & $-0,019$ & 0,074 & $-0,016$ & & \\
\hline $\mathrm{HI} \times$ płeć & $-0,010$ & 0,067 & $-0,003$ & & \\
\hline VI $\times$ płeć & 0,165 & 0,066 & $0,144^{*}$ & & \\
\hline VC $\times$ płeć & 0,016 & 0,070 & 0,014 & & \\
\hline Doświadczenie $\mathrm{HC} \times$ płeć & 0,068 & 0,087 & 0,059 & & \\
\hline Doświadczenie $\mathrm{HI} \times$ płeć & $-0,242$ & 0,068 & $-0,211^{* *}$ & & \\
\hline Doświadczenie VI × płeć & $-0,055$ & 0,077 & $-0,048$ & & \\
\hline
\end{tabular}

${ }^{*} p<0,05 ;{ }^{* *} p<0,01$.

W pierwszym modelu do analizy wprowadzono następujące zmienne: płeć (zakodowaną na dwóch poziomach: $-1 \mathrm{i}+1$, odpowiednio dla mężczyzn i kobiet) oraz cztery orientacje Ja: HC, HI, VC i VI. Uzyskano model nieistotny statystycznie: $F(5,296)=1,7 ; p>0,13$. W modelu tym jedynym znaczącym 
statystycznie predyktorem zadowolenia była orientacja HC $($ Beta $=0,132)$. Zważywszy jednak na to, że w podgrupach płciowych nie uzyskano istotnych korelacji między tą orientacją a zadowoleniem, należy uznać, że jest to związek bardzo słaby. W modelu drugim do zmiennych $\mathrm{z}$ modelu pierwszego dodano pozytywność doświadczenia: $\mathrm{HC}_{\text {dos }}, \mathrm{HI}_{\text {dos }} \mathrm{i} \mathrm{VI}_{\text {dos }}$. Uzyskano model istotny statystycznie: $F(8,293)=16,29 ; p<0,001$; skor. $R^{2}=0,29$ oraz istotny efekt zmiany: $\Delta R^{2}=0,28 ; p<0,001$. W drugim modelu istotnymi predyktorami zadowolenia były dwa rodzaje doświadczeń: $\mathrm{HC}_{\mathrm{dos}}$ : Beta $=0,202 ; p<0,001$ oraz $\mathrm{HI}_{\mathrm{dos}}$ : Beta $=0,503 ; p<0,001$. Ani płeć badanych, ani żadna orientacja społeczna Ja nie wpływała bezpośrednio na zadowolenie ze studiów. W modelu trzecim do zmiennych z modelu drugiego dodano zmienne interakcyjne między rodzajem doświadczenia i rodzajem orientacji, płcią i rodzajem orientacji, płcią i rodzajem doświadczenia. Ponownie uzyskano model istotny statystycznie: $F(19$, $282)=8,39 ; p<0,0001$ oraz słaby, lecz istotny efekt zmiany modelu: $\Delta R^{2}=0,053$; $p<0,05$. W trzecim modelu uzyskano następujące predyktory zadowolenia: VI: Beta $=-0,159, p<0,05 ; \mathrm{HC}_{\mathrm{dos}}:$ Beta $=0,183, p<0,05$ HI $_{\mathrm{dos}}:$ Beta $=0,599$, $p<0,001$; efekt interakcyjny płci z doświadczeniem $\mathrm{HI}_{\mathrm{dos}}:$ Beta $=-0,211, p<0,001$ oraz efekt interakcyjny płci z orientacją VI: Beta $=0,144, p<0,05$. Podobnie jak $\mathrm{w}$ modelu drugim, doświadczenia $\mathrm{w}$ sferze partnerskich relacji koleżeńskich $\left(\mathrm{HC}_{\mathrm{dos}}\right)$ oraz autonomii $\left(\mathrm{HI}_{\mathrm{dos}}\right)$ były pozytywnymi wyznacznikami zadowolenia, ponadto ujemnym predyktorem okazało się nastawienie na rywalizację (VI). $\mathrm{W}$ celu interpretacji istotnych statystycznie efektów interakcyjnych wykonano dodatkowe analizy. Na podstawie wartości median wyodrębniono dwa poziomy doświadczenia $\mathrm{HI}_{\mathrm{dos}}(M e=4,75)$ oraz dwa poziomy orientacji VI $(M e=5,33)$. Następnie dla zadowolenia ze studiów wykonano dwie dwuczynnikowe analizy wariancji w schematach (1) płeć $\times$ doświadczenie $\mathrm{HI}_{\text {dos }}$ oraz (2) płeć $\times$ orientacja VI. Pierwsza analiza wariancji wykazała bardzo silny efekt główny doświadczenia $\mathrm{HI}_{\text {dos }}$ dla zadowolenia: $F(1,298)=77,87 ; p<0,0001 ; \eta^{2}=0,21$ oraz znacznie słabszy efekt interakcyjny płci i doświadczenia $\mathrm{HI}_{\mathrm{dos}}: F(1,298)=6,35$; $p<0,05 ; \eta^{2}=0,02$, polegający na tym, że wśród osób $\mathrm{z}$ niższym poziomem zaspokojenia potrzeby autonomii kobiety $(M=4,52)$ były bardziej zadowolone niż mężczyźni $(M=4,13)$. Wielkość różnicy była jednak niewielka $(d=-0,34)$. Zgodnie z silnym efektem głównym w obu grupach płciowych osoby z wyższym poziomem zaspokojenia potrzeby autonomii były bardziej zadowolone ze studiów $\left(M_{\text {kobiety }}=5,34 ; M_{\text {mécczýni i }}=5,6\right)$. Druga analiza wariancji, w schemacie płeć $\times$ orientacja VI, nie wykazała żadnych istotnych zależności $(F<1)$. Niemniej jednak analizy korelacyjne (por. tabela nr 4) pokazują, że w grupie mężczyzn orientacja VI korelowała negatywnie $\mathrm{z}$ zadowoleniem $(r=-0,22 ; p<0,05)$, $\mathrm{w}$ grupie kobiet natomiast obie zmienne były od siebie niezależne.

Podsumowując uzyskane wyniki analizy regresji, można powiedzieć, że bezpośrednimi predyktorami zadowolenia ze studiów są pozytywne doświadczenia w sferach HC i HI. Płeć badanych różnicuje tylko w niewielkim stopniu 
prawidłowości związane z osiąganiem dobrostanu: w wypadku mężczyzn orientacja VI utrudnia (w słabym stopniu) osiąganie zadowolenia, dla zadowolenia kobiet nie wykazano znaczenia tej orientacji. Pozostałe orientacje nie decydują bezpośrednio o poziomie zadowolenia ze studiów. Słabsze zaspokojenie potrzeby autonomii ma ponadto większy negatywny wpływ na zadowolenie mężczyzn niż kobiet. Nie wykazano żadnych efektów interakcyjnych orientacji społecznych Ja $z$ rodzajem odpowiadającego im doświadczenia, co może oznaczać, że wpływ określonego doświadczenia na zadowolenie ze studiów jest względnie niezależny od siły orientacji.

\section{Dyskusja}

Poszukując zależności między orientacjami społecznymi Ja i doświadczeniem zdobywanym na studiach a zadowoleniem ze studiów, sformułowano trzy alternatywne hipotezy (Singelis i in., 1995; Triandis, Gelfand, 1998).

Pierwsza $z$ nich przewidywała, że orientacje społeczne Ja różnicują wagę doświadczeń zdobywanych na studiach, a zatem ten sam rodzaj doświadczenia może w odmienny sposób wpływać na zadowolenie ze studiów, w zależności od nasilenia orientacji. Pozytywna weryfikacja tej hipotezy wymagała wykazania istotnych statystycznie efektów interakcyjnych między orientacjami Ja i doświadczeniem na studiach dla ocen zadowolenia. Prawidłowości takich jednak nie wykazano. Uzyskano za to dowód na bezpośredni wpływ doświadczenia $\mathrm{w}$ sferze relacji koleżeńskich $\left(\mathrm{HC}_{\mathrm{dos}}\right)$ oraz autonomii $\left(\mathrm{HI}_{\mathrm{dos}}\right)$ na zadowolenie ze studiów, niezależnie od nasilenia czterech orientacji Ja. Rezultat ten może wynikać z dwóch powodów. Po pierwsze z prawidłowości mówiącej, że zaspokajanie potrzeb w tych dwóch sferach ma dobroczynny wpływ na dobrostan psychiczny każdej jednostki (Leary, Baumeister, 1995; Deci, Ryan, 2000), niezależnie od świadomie deklarowanych ocen ich ważności. Po drugie z faktu, że zdecydowana większość badanych studentów miała wysokie nasilenie orientacji horyzontalnych oraz zaledwie umiarkowane nasilenie orientacji wertykalnych (por. tabela 3), a zatem grupa mogła być zbyt jednorodna, aby wykazać wpływ nasilenia orientacji społecznych Ja na zadowolenie ze studiów.

Druga hipoteza przewidywała, że orientacje społeczne Ja przyczyniają się do zadowolenia ze studiów w niejednakowym zakresie, gdyż wiążą się z pragnieniami, które w różnym stopniu ułatwiają osiągnięcie dobrostanu psychicznego. Orientacja horyzontalnego kolektywizmu, afirmująca bliskie, partnerskie relacje koleżeńskie (HC), oraz orientacja horyzontalnego indywidualizmu (HI), skoncentrowana na rozwoju własnej aktywności i zachowaniu autonomii, zdają się najlepiej przyczyniać do osiągnięcia pełnego dobrostanu psychicznego jednostki (Argyle, 2004; Nezleck, 2004; Baumeister, Leary, 1995; Deci, Ryan, 2000; Ryan, Deci, 2000). Orientacje wertykalne, związane z potrzebą faworyzowania Ja i rywalizacją z innymi (VI) lub koniecznością podporządkowania się grupie 
(VC), mogą z kolei utrudniać osiągnięcie dobrostanu psychicznego (Singelis i in., 1995; Triandis, Gelfand, 1998). Uzyskane wyniki nie wykazały jednak znaczącego bezpośredniego wpływu orientacji Ja na zadowolenie ze studiów. Tylko w grupie mężczyzn orientacja wertykalnego indywidualizmu (VI) w niewielkim stopniu korelowała negatywnie z zadowoleniem $(r=-0,22)$. W grupie kobiet orientacje Ja wprawdzie nie wiązały się bezpośrednio z zadowoleniem ze studiów, to jednak korelowały pozytywnie (w umiarkowanym lub niskim stopniu) $\mathrm{z}$ doświadczeniem odpowiadającym tym orientacjom. Oznacza to, że badane osoby z silniejszą orientacją horyzontalnego kolektywizmu (HC) oraz horyzontalnego indywidualizmu (HI) trochę lepiej zaspokajały potrzeby ważne dla dobrostanu psychicznego. W grupie mężczyzn tylko orientacja HC korelowała pozytywnie (w umiarkowanym stopniu) z doświadczeniem w tej sferze, $\mathrm{w}$ sferze autonomii (HI) i rywalizacji (VI) natomiast pozytywność doświadczenia nie wiązała się z nasileniem odpowiadających im orientacji. Tak więc mężczyźni wyżej niż inni ceniący autonomię nie doświadczali jej bynajmniej w większym stopniu, a mężczyźni bardziej nastawieni na rywalizację niekoniecznie czuli się lepsi od innych w grupie studenckiej. Możliwe zatem, że nastawienie na rywalizację wpłynęło ujemnie na zadowolenie badanych mężczyzn, gdyż studenci ceniący rywalizację niekoniecznie wychodzili z niej zwycięsko.

Uzyskane wyniki zdają się najpełniej potwierdzać hipotezę trzecią, mówiącą o względnej niezależności zadowolenia ze studiów od orientacji społecznych Ja. Wskazują również na uniwersalne znaczenie pozytywnego doświadczenia $\mathrm{w}$ sferze autonomii i partnerskich relacji koleżeńskich dla zadowolenia ze studiów. Niezależnie od tego, jak bardzo jednostka ceni relacje koleżeńskie, jeśli są one udane - czerpie $\mathrm{z}$ nich równie silne zadowolenie. I niezależnie od tego, jak bardzo ceni (świadomie) autonomię, to jej doświadczanie wpływa korzystnie na zadowolenie. Niemniej jednak do takiej interpretacji należy podejść ostrożnie, gdyż w badanej grupie większość wyników dla orientacji HI oraz HC sytuowała się powyżej średniej, a zatem ich niską wartość deklarowała znikoma liczba badanych.

Badania wykazały niewielkie różnice płciowe w zakresie nasilenia orientacji społecznych Ja oraz rodzaju doświadczenia zdobywanego na studiach. Zgodnie ze stereotypem płciowym podkreślającym wspólnotowy charakter relacji kobiet $\mathrm{z}$ otoczeniem kobiety charakteryzowały się trochę silniejszym horyzontalnym kolektywizmem niż mężczyźni, ale mężczyźni nie osiągnęli bynajmniej przewagi nad kobietami w nasileniu orientacji indywidualistycznych. Podobne dla obu płci były też prawidłowości związane z osiąganiem zadowolenia ze studiów. W całej grupie wysokie nasilenie obu orientacji horyzontalnych oraz słabsze od nich umiarkowane nasilenie orientacji wertykalnych oznaczają, że wśród badanych studentów (kobiet i mężczyzn) dominowały postawy demokratyczne - równościowe, zarówno o charakterze indywidualistycznym, jak i kolektywistycznym. Nastawienie na dobre relacje koleżeńskie oraz zachowanie autonomii (swobodę 
działania, rozwijanie własnych zainteresowań) było powszechne i znacznie silniejsze niż postawy autorytarne i rywalizacyjne.

\section{OgRANICZENIA WE WNIOSKOWANIU}

W badanej próbie niewielu studentów charakteryzowało się niskim nasileniem orientacji horyzontalnych i wysokim nasileniem orientacji wertykalnych. Niewykluczone zatem, że przy bardziej zróżnicowanych wynikach dla orientacji Ja uzyskano by prawidłowości bardziej wyraziste, wskazujące na bezpośredni wpływ orientacji społecznych Ja na rodzaj zdobywanego doświadczenia i zadowolenie ze studiów. Trudno np. wyobrazić sobie, aby osoby silnie skoncentrowane na rywalizacji miały równie pozytywne doświadczenie w sferze partnerskich relacji koleżeńskich, jak osoby z silnymi orientacjami horyzontalnymi. Podobnie mało prawdopodobne jest, żeby osoby silnie skoncentrowane na partnerskich, bliskich relacjach koleżeńskich intensywnie się faworyzowały - doświadczały bycia lepszymi od innych.

W zaprezentowanych badaniach przyjęto określony kierunek przewidywanych zależności: orientacje społeczne Ja mogą wpływać na rodzaj zdobywanego doświadczenia na studiach. Niewykluczone jednak, że nowe doświadczenie nabywane w czasie studiów, odmienne od wcześniejszego z powodu zmiany środowiska i trybu życia (oddalenie od domu rodzinnego i dawnych kolegów, mniej rygorystyczny system uczęszczania na zajęcia itp.), może powodować zmiany w nasileniu tychże orientacji. W związku z tym warto podjąć badania podłużne, obejmujące studentów na początku i na końcu okresu studiów, weryfikujące taką zależność.

Dalszej pracy wymaga metoda do badania doświadczenia na studiach, gdyż nie udało się wyodrębnić osobnej skali dla doświadczenia w sferze wertykalnego kolektywizmu. Jedną z przyczyn może być sama organizacja studiowania: formalnie studenci są zależni od grupy w niewielkim stopniu: nauka i system oceniania mają charakter indywidualny, a zatem okazji do „uznania hierarchii” i podporządkowania własnych potrzeb interesom grupy może być stosunkowo niewiele. Konieczności podporządkowania się grupie oraz uznania autorytetów studenci mogą doświadczać prawdopodobnie znacznie częściej w rodzinie bądź wspólnotach religijnych niż w grupie studenckiej.

Sprawą otwartą pozostaje, czy wyniki uzyskane dla czterech orientacji społecznych Ja są typowe dla całej populacji polskich studentów. Wprawdzie osobami badanymi byli studenci różnych kierunków studiów (psychologii, pedagogiki, socjologii, filozofii i prawa), lecz wszyscy studiowali na tej samej wyższej uczelni (UKSW), nie można więc uznać, że zaprezentowane wyniki są reprezentatywne dla wszystkich studentów w Polsce. 


\section{Bibliogr AFIA}

Argyle, M. (2004). Psychologia szczęścia. Wydawnictwo ASTRUM, Wrocław. Baumeister, R. F., DeWall, C. N., Ciarocco, N. J., Twenge, J. M. (2005). Social exclusion impairs self-regulation. Journal of Personality and Social Psychology, $88,589-604$.

Baumeister, R. F., Leary, M. R. (1995). The need to belong: desire for interpersonal attachments as a fundamental human motivation. Psychological Bulletin, 117, 497-529.

Cross, S. E., Madson, L. (1997). Models of the self: Self-construal theory and gender. Psychological Bulletin, 122, 5-37.

Deci, E. L., Ryan, R. M. (2000). The „what” and „why” of goal pursuits: Human needs and the self-determination of behavior. Psychological Inquiry, 11, 319-338.

Diener, E., Emmons, R. A., Larson, R. J., Griffin, S. (1985). The satisfaction with life scale. Journal of Personality Assesment, 49, 71-75.

Diener, E., Lucas, R. E., Oishi, S. (2004). Dobrostan psychiczny. Nauka o szczęściu i zadowoleniu z życia. W: J. Czapiński (red.), Psychologia pozytywna. Nauka o szczęściu, zdrowiu, sile i cnotach człowieka (s. 35-51). Warszawa: Wydawnictwo Naukowe PWN.

Eagly, A. (1987). Sex differences in social behavior: A social-role interpretation. Hillsdale: NJ: Erlbaum.

Heilman, M. E., Chen, J. J. (2005). Same behavior, different consequences: Reactions to men's and women's altruistic citizenship behavior. Journal of Applied Psychology, 90, 431-441.

Levinson, D. J. (1986). A conception of adult development. American Psychologist, $41,3-13$.

Marcia, J. (1980). Identity in adolescence. W: J. Adelson (red.), Handbook of adolescent psychology (s. 159-187). New York: Wiley.

Nezleck, J. B. (2004). Motywacyjna i poznawcza dynamika codziennego życia społecznego. W: J. P. Forgas, K. D. Williams, L. Wheeler (red.), Umysł społeczny (s. 110-128). Gdańsk: Gdańskie Wydawnictwo Psychologiczne.

Rudman, L. A., Fairchild, K. (2004). Reactions to counterstereotypic behavior: The role of backlash in cultural stereotype maintenance. Journal of Personality and Social Psychology, 87, 157-176.

Ryan, M. R., Deci, E. L. (2000). Self-determination theory and the facilitation of intrinsic motivation, social development, and well-being. American Psychologist, 55, 68-78.

Singelis, Th. M., Triandis, H. C., Bhawuk, Dh. P. S., Gelfland, M. J. (1995). Horizontal and vertical dimensions of indyvidualism and collectivism: A theoretical and measurement refinement. Cross-Cultural Research, 29, 240-275.

Triandis, H. C., Gelfand, M. J. (1998). Converging measurement of horizontal and vertical individualism and collectivism. Journal of Personality and Social Psychology, 74, 118-128. 


\section{ZAeĄCZNiK A}

\section{MOJE DOŚWIADCZENIA NA STUDIACH}

Wiek: Płeć.

Data badania

Uczelnia.

Kierunek i rok studiów.

Poniżej znajdziesz 16 zdań dotyczacych różnych obszarów funkcjonowania na studiach. Używając skali 1-7, oceń, w jakim stopniu każde z poniższych zdań odnosi się do Ciebie. Zaznacz odpowiedni numer. 1 oznacza „zupetnie tak nie jest”, 7 natomiast - „zdecydowanie tak jest”. Pamiętaj: badanie jest anonimowe, licza się tylko szczere odpowiedzi.

1. Zwykle w dyskusji z kolegami mam do powiedzenia więcej 1234567 od innych.

2. Zwykle koledzy pytają mnie o radę w ważnych dla grupy 1234567 sprawach.

3. Mam na studiach dużą swobodę: robię to, co lubię. 1234567

4. Miło spędzam czas z kolegami po zajęciach. 1234567

5. Z przedmiotów, które są dla mnie ważne, uzyskuję oceny lepsze 1234567 od innych*.

6. Koledzy liczą się z moją opinią na różne tematy*. 1234567

7. Na studiach mogę zachować własną prywatność - nikt nie 1234567 wtrąca się w moje sprawy.

8. Mogę liczyć na wzajemną pomoc kolegów i koleżanek. 1234567

9. Prowadzący wyróżnia moje opinie podczas dyskusji grupowej 1234567 na zajęciach.

10. Studia, na których jestem, pomogą mi znaleźć pracę, dzięki 1234567 której w razie potrzeby będę mógł wesprzeć moich bliskich*.

11. Rozwijam swoje umiejętności dzięki zajęciom organizowanym 1234567 przez uczelnię.

12. Koledzy i koleżanki ze studiów cieszą się, kiedy jestem w ich 1234567 towarzystwie.

13. Moje prace zaliczeniowe należą do jednych z ciekawszych. 1234567

14. Łatwo podporządkowuję się interesom grupy, nawet jeżeli jest 1234567 to niezgodne z moimi potrzebami*.

15. Prowadzący zajęcia pozwalają mi na kreatywność i swobodę 1234567 wypowiedzi.

16. Na studiach nawiązałem nowe znajomości i przyjaźnie.

* Zdania, które nie weszły do ostatecznej wersji metody. 